IZA DP No. 5377

Labor Market Developments in China:

A Neoclassical View

Suqin $\mathrm{Ge}$

Dennis Tao Yang

December 2010 


\title{
Labor Market Developments in China: A Neoclassical View
}

\author{
Suqin Ge \\ Virginia Tech \\ Dennis Tao Yang \\ Chinese University of Hong Kong \\ and IZA

\section{Discussion Paper No. 5377 \\ December 2010} \\ IZA \\ P.O. Box 7240 \\ 53072 Bonn \\ Germany \\ Phone: +49-228-3894-0 \\ Fax: +49-228-3894-180 \\ E-mail: iza@iza.org
}

\begin{abstract}
Any opinions expressed here are those of the author(s) and not those of IZA. Research published in this series may include views on policy, but the institute itself takes no institutional policy positions.

The Institute for the Study of Labor (IZA) in Bonn is a local and virtual international research center and a place of communication between science, politics and business. IZA is an independent nonprofit organization supported by Deutsche Post Foundation. The center is associated with the University of Bonn and offers a stimulating research environment through its international network, workshops and conferences, data service, project support, research visits and doctoral program. IZA engages in (i) original and internationally competitive research in all fields of labor economics, (ii) development of policy concepts, and (iii) dissemination of research results and concepts to the interested public.
\end{abstract}

IZA Discussion Papers often represent preliminary work and are circulated to encourage discussion. Citation of such a paper should account for its provisional character. A revised version may be available directly from the author. 
IZA Discussion Paper No. 5377

December 2010

\section{ABSTRACT}

\section{Labor Market Developments in China: A Neoclassical View ${ }^{\star}$}

This paper assesses the applicability of two alternative theories in understanding labor market developments in China: the classical view featuring a Lewis turning point in wage growth versus a neoclassical framework emphasizing rational choices of individuals and equilibrating forces of the market. Empirical evidence based on multiple data sources fails to validate the arrival of the Lewis turning point in China, showing continuous and coordinated wage growth across rural and urban sectors instead. Consistent with the neoclassical view, we find that rural workers expanded off-farm work when mobility restrictions were lifted, interprovincial migration responded to expected earnings and local employment conditions, and returns to education converged gradually to the international standard. These findings suggest major progresses in the integration of labor markets in China.

JEL Classification: J31, J21, O11

Keywords: $\quad$ labor markets, rural-urban migration, wage growth, schooling returns, Lewis turning point, China

Corresponding author:

Dennis T. Yang

Department of Economics

Chinese University of Hong Kong

Shatin, N.T.

Hong Kong

E-mail: deyang@cuhk.edu.hk

\footnotetext{
* The authors would like to thank the seminar participants at Fudan University for their valuable comments. We are also grateful to Jessie Pang for her excellent research assistance. We would also like to acknowledge financial support from the Research Grants Council of the Hong Kong Special Administrative Region (China) and the CCK Foundation for Scholarly Exchange, as well as research support from the Hong Kong Institute of Asia-Pacific Studies.
} 


\section{Introduction}

In the past two decades, China's emergence as the global manufacturing center has relied largely on its abundant human resources. However, since 2004, China began to experience periods of labor shortages in the Pearl River Delta and Yangtze River Delta regions because employers were reported to have had difficulties in recruiting migrant labor (Huang, 2004). Thereafter anxiety over rising wages in China has been widespread. Among other studies, Cai and Wang (2010) and Cai and Du (2010) document that, after a long period of stagnation, wages of unskilled labor in China rose rapidly in the early years of the new century. They take wage growth as an indication of the Lewis turning point, where rural surplus labor is depleted, thus pushing up wages. Using village survey data from several provinces, Zhang et al. (2010) draw a similar conclusion. ${ }^{1}$

The notion that China is quickly approaching or has already reached the Lewis turning point is not without controversy. An opposing view stresses the fact that China still has a considerable pool of surplus labor in the rural sector (Knight et al., 2010; Minami and Xin, 2008). However, to date, only limited attempts have been made to examine the patterns of wage growth across rural and urban sectors as implied by the classical theory of the turning point. Fundamentally, there is still an open question about the usefulness of the Lewisian model for understanding the evolution of Chinese labor markets in the past three decades.

In a seminal paper, Lewis (1954) proposed a theory of economic development featuring the dualistic structure of a traditional (agricultural) and a modern (industrial) sector. In the initial phase of development, there is abundance of labor in the agricultural sector, where an institutional wage is set above the marginal product of labor. Industrialization can be supported cheaply during this phase because the industrial sector faces unlimited labor supply at a low, fixed real wage. With continued industrialization, the economy reaches a Lewis turning point once the rural surplus labor is depleted. From this point, the industry faces an upward-sloping labor supply curve, which implies sharp increases in real wage with further growth. This classic view of economic development provided important insight for understanding the transformation of a dual economy and was influential in the history of economic thought. However, in the 1960s, an alternative neoclassical theory of development emerged,

\footnotetext{
${ }^{1}$ Anxiety over rising labor costs has also attracted attention from the media and Chinese government research institutions. The Economist (January 11, 2007) notes that pay for factory workers has been rising at "double-digit rates for several years." The New York Times (August 29, 2007) profiles a number of factory managers having difficulty finding workers and dealing with wage rises. In a 2007 survey covering 2749 villages, the Development Research Center of the State Council found that three-quarters of the villages no longer had suitable young labor to transfer out of agriculture. In its 2007 Green Book on Population and Labor, The Institute of Population and Labor Economics at the Chinese Academy of Social Sciences (CASS) also implied that China was around the Lewis turning point. Both of these studies forecast severe labor shortages and an acceleration of wage rises in China starting as early as 2009 or 2010.
} 
and it has been adopted widely in the study of development issues. This neoclassical theory, as exemplified in the work of Schultz (1964), emphasizes the rational choices of individuals and families in decision making. Contrary to the classical view, wages are determined by equilibrating forces of the markets rather than being set institutionally. Therefore, labor is never available to the industrial sector without sacrificing agricultural output. The real wage in the industrial sector rises steadily over time, and a distinctive turning point never exists.

The purpose of this paper is to evaluate the applicability of the two alternative theories in understanding labor market development in China: the classical view featuring a Lewis turning point in wage growth versus a neoclassical framework emphasizing rational choices of individuals and equilibrating forces of the market. We first lay out a simple and comparable version of the classical and neoclassical theories of economic development and derive a set of contrasting yet testable implications. Multiple sources of data are deployed to test empirically the predictions of the models. In particular, we are able to construct and examine the changing wage levels over time for agricultural workers, rural off-farm employment, rural migrants, and urban unskilled workers, drawing aggregate data from the Statistical Yearbooks of China (SYC) and individual information from the Urban Household Surveys (UHS) and China Health and Nutrition Surveys (CHNS).

We find that while migrant wages have increased in recent years, they are an integral component of overall wage growth that has occurred continuously in the past two decades. Empirical evidence from multiple data sources fails to support the arrival of the Lewis turning point in China, showing coordinated wage growth across rural and urban sectors instead. Consistent with the neoclassical view, we find that rural workers expanded off-farm work during the reform process, interprovincial migration responded to expected earnings and local employment opportunities, and rates of return to education have increased significantly in both rural and urban labor markets in recent years, converging steadily to the level of international norm. These findings suggest that major progresses have been made towards the integration of labor markets in China.

The rest of the paper is organized as follows. Section 2 summarizes the classical and neoclassical views of economic development and derives a set of testable implications from the two theories. Section 3 provides an overview of the dual economy and labor market institutions in China and uses several sources of aggregate and household data to examine empirically the implications of the alternative frameworks. Section 4 presents the concluding remarks. 


\section{Alternative Views of Economic Development}

T.W. Schultz and Arthur Lewis were awarded the 1979 Nobel prize for their pioneering research on economic development. While Lewis originally proposed the classical theory, Schultz was a pioneer who helped lay out the foundations of the neoclassical development theory. Other economists, such as Ranis and Fei (1961) and Jorgenson (1967), also made major contributions. In this section, we present a simple version of the classical and neoclassical models with comparable settings to highlight the main mechanisms of development and derive a set of contrasting yet testable implications from the alternative models.

\subsection{The Classical Lewis Model}

Lewis (1954) divides a typical developing economy into two sectors: a traditional (agriculture) sector and a modern (industrial) sector. He uses a two-sector model to study the expansion of the modern sector, which absorbs cheap labor from the traditional sector. In the traditional sector, population size is large compared with land; therefore, the marginal productivity of labor is close to zero. As the modern sector continues to expand, rural surplus labor will eventually disappear, pushing up wages. This transition from "unlimited supply of labor" to labor shortage is known as the Lewis turning point.

In what follows, we describe the Lewis model in detail. The conceptual framework follows closely that of Ranis and Fei (1961). For simplicity, we consider an economy with no technological progress or population growth. ${ }^{2}$

\section{The Agricultural Sector}

Consider an economy where all production takes place in the agricultural sector. The output of the agricultural sector is a constant-returns-to-scale function of labor and land. Suppose that there is no capital investment in the agricultural sector and that land is fixed in supply.

Let $Y_{t}^{A}$ be the agricultural output, $X_{t}$ the fixed quantity of land, and $L_{t}^{A}$ the agricultural labor input. The production function is assumed to be Cobb-Douglas: $Y_{t}^{A}=X_{t}^{\beta}\left(L_{t}^{A}\right)^{1-\beta}$, where $1-\beta$ is the elasticity of output with respect to labor. The supply of land is fixed; thus, we simplify the production function as $Y_{t}^{A}=\left(L_{t}^{A}\right)^{1-\beta}$.

The economy under consideration is labor abundant and resource scarce. By assumption, if agricultural labor input is above $\bar{L}$, additional labor input does not produce more output. In other words, total population $P$ is the sum of the maximum agricultural labor force $\bar{L}$ employed at positive marginal productivity and redundant labor $R$ with zero marginal

\footnotetext{
${ }^{2}$ The model can be extended to consider technological progress and population growth in both sectors. However, the basic implications remain very similar.
} 
productivity. Therefore, the agricultural production function is given by

$$
Y_{t}^{A}=\left\{\begin{array}{cc}
\left(L_{t}^{A}\right)^{1-\beta} & \text { if } 0 \leq L_{t}^{A}<\bar{L} \\
\bar{L}^{1-\beta} & \text { if } \bar{L} \leq L_{t}^{A} \leq P
\end{array},\right.
$$

and marginal productivity of labor in agricultural sector is determined by

$$
M P L_{t}^{A}=\left\{\begin{array}{cl}
(1-\beta)\left(L_{t}^{A}\right)^{-\beta} & \text { if } 0 \leq L_{t}^{A}<\bar{L} \\
0 & \text { if } \bar{L} \leq L_{t}^{A} \leq P
\end{array}\right.
$$

At the initial point $(t=0)$, let the entire population be devoted to agricultural production, producing a total agricultural output of $Y^{*}=\bar{L}^{1-\beta}$. Ranis and Fei (1961) assumes that total agricultural output is consumed by the total labor force $P$. The real wage is set to the average product of labor. This wage, measured in agricultural goods, is called institutional wage and is equal to ${ }^{3}$

$$
w^{*}=\frac{\bar{L}^{1-\beta}}{P} .
$$

The key assumption is that "this wage is based on some institutional sharing arrangement rather than on the marginal productivity calculus" (Ranis, 1988). If the market is competitive, real wage will be equal to the marginal productivity of labor and fall to zero.

Let $D$ be the point at which the marginal product of labor equals the institutional wage; therefore,

$$
D=[(1-\beta) P]^{1 / \beta} \bar{L}^{1-1 / \beta}
$$

Among the total agricultural labor force $P, P-\bar{L}$ are redundant workers because they have zero marginal product, and $P-D$ are disguised unemployed workers because the marginal product of labor is below the institutional wage.

\section{The Industrial Sector}

The industrial sector also has a constant-returns-to-scale production technology. Denote $Y_{t}^{M}$ as the industrial output, $L_{t}^{M}$ the industrial labor input, and $K$ the quantity of capital. The production function takes the Cobb-Douglas form:

$$
Y_{t}^{M}=K_{t}^{\sigma}\left(L_{t}^{M}\right)^{1-\sigma}
$$

\footnotetext{
${ }^{3}$ We assume that $\bar{L}>P(1-\beta)$ holds such that the institutional wage is greater than the marginal product of labor when agricultural labor force is equal to $\bar{L}$.
} 
In the industrial sector, wage equals the marginal product of labor, which is determined by:

$$
M P L_{t}^{M}=(1-\sigma) K_{t}^{\sigma}\left(L_{t}^{M}\right)^{-\sigma}
$$

The industrial sector differs from the agricultural sector in two aspects. First, there is capital investment in the industry, and capital is a key input. Second, labor market is competitive in the modern sector.

\section{Phases of Development and the Lewis Turning Point}

In the first phase of economic development, redundant labor in the agricultural sector is available to the industrial sector at a fixed real wage, $w^{*}$, measured in agricultural goods. The marginal product of labor equals zero in the agricultural sector at this stage. Therefore, reallocation of labor to the industrial sector has no effect on agricultural output. As long as there exists redundant labor in the agricultural sector, the industrial sector faces a perfect elastic labor supply curve at the fixed real wage measured in manufacturing goods. During this phase, industrial employment can grow up to $P-\bar{L}$, the size of redundant labor in the agricultural sector, and the real wage stays fixed over time. Ranis and Fei define the "Lewis turning-point" as the threshold point at which redundant rural labor disappears.

The second stage of economic development refers to the period when agricultural redundant labor has depleted, but the marginal productivity of labor in the agricultural sector is still below the institutional wage. Just like in the first phase, the industrial sector only needs to pay the institutional wage $w^{*}$ (measured in agricultural goods) to attract agricultural labor. However, when labor moves out of the agricultural sector, agricultural output declines because of the positive marginal product of labor. Suppose the demand for agricultural goods is fixed, falling agricultural output would drive up the price of agricultural goods. ${ }^{4}$ The institutional wage measured in industrial goods increases as the terms of trade turns against manufacturing. In the second phase of development, industrial employment continues to grow until it reaches $P-D$, the size of disguised unemployment. The real wage, measured in industrial goods, starts growing due to the worsening of the terms of trade for the industrial sector.

The third phase of economic development arrives when the transfer of disguised unemployed labor from the agricultural sector is completed. From that time on, real wage will be determined by the marginal productivity of labor in the agricultural sector, and the industrial and agricultural sectors will compete for the scarce labor. The industrial sector then faces an upward-sloping labor supply curve. The real wage will start to grow fast for two

\footnotetext{
${ }^{4}$ This assumption is made by Ranis and Fei (1961).
} 
reasons: (1) the terms of trade for the industrial sector continues to deteriorate, and (2) the agricultural real wage determined by marginal productivity continues to increase.

\subsection{The Neoclassical Model of Development}

The neoclassical model of economic development assumes positive labor productivity in the agricultural sector so that labor is never redundant. The real wage in the agricultural sector changes with the evolving conditions of development. In Jorgenson (1967)'s version of neoclassical development model, wage rate in the agricultural sector is assumed to be proportional to that in the industrial sector. Another crucial contrast to the classical model is that the growth of an agricultural surplus determines the rate of growth of industrial employment.

In the Jorgenson model, the agricultural production technology is similar to that in the classical model: $Y_{t}^{A}=e^{\alpha t} X_{t}^{\beta}\left(L_{t}^{A}\right)^{1-\beta}$, where $\alpha$ is the constant growth rate of technological progress, and all the other variables and parameters have the same interpretation as in the Lewis model. The supply of land is assumed to be fixed, and this production function may be rewritten in the simpler form of

$$
Y_{t}^{A}=e^{\alpha t}\left(L_{t}^{A}\right)^{1-\beta}
$$

Agricultural output per person is determined by

$$
y_{t}^{A}=\frac{Y_{t}^{A}}{L_{t}^{A}}=e^{\alpha t}\left(L_{t}^{A}\right)^{-\beta} .
$$

Initially, all economic activities take place in the agricultural sector. Therefore, $L_{t}^{A}=P$, where $P$ is the total population.

The production function of the industrial sector also takes the Cobb-Douglas form with constant-returns-to-scale technology:

$$
Y_{t}^{M}=e^{\lambda t} K_{t}^{\sigma}\left(L_{t}^{M}\right)^{1-\sigma}
$$

where $\lambda$ is a constant growth rate of technological progress, and all the other variables and parameters are the same as the classical model. The neoclassical model also assumes a critical value of agricultural output per person, $y^{+}$, above which all additional consumption is devoted to manufactured goods. Therefore, agricultural output per person $\left(y_{t}^{A}\right)$ in excess 
of $y^{+}$constitutes an agricultural surplus $s_{t}$ :

$$
s_{t}=y_{t}^{A}-y^{+}
$$

If agricultural output per person is below the critical value, the entire labor force works in the agricultural sector. Once $y_{t}^{A}$ exceeds $y^{+}$, part of the labor force may be released from agriculture to produce manufactured goods. Therefore, given positive initial capital stock, a growing agricultural surplus leads to an expansion of the industrial labor force and sustained growth in the economy.

Agricultural workers are willing to move to the industrial sector if industrial wages are greater than agriculture income. Jorgenson (1967) assumes that the wage differential necessary to attract agricultural labor into the industrial sector is roughly proportional to the industrial wage rate. Let $\mu \leq 1$ denote the ratio between agricultural income and industrial wage. In a "perfect" neoclassical theory without market frictions, wage rates in the two sectors must be equal. As such, the proportionality $\mu=1$. If the industrial sector compensates agricultural workers for migration cost and higher cost of living in cities, $\mu$ would be below unity.

\subsection{Implications on Wage Growth}

The classical Lewis model characterizes rural labor markets as uncompetitive in the early stage of development. Rural wages are assumed to be institutionally determined at levels above the market equilibrium of zero marginal product of labor. Real wages in the agricultural and industrial sectors are stagnant initially. ${ }^{5}$ The turning point marks the end of wage stagnation in the industrial sector and signals the beginning of large wage increases. After the turning point, the industrial sector faces an upward-sloping labor supply curve. ${ }^{6}$

In contrast, the neoclassical model characterizes rural labor markets in developing economies as competitive. Rural wages reflect positive marginal product of labor. The neoclassical model implies that development involves continuous increases in marginal productivity of labor in both agricultural and industrial sectors so that their real wages rise continuously. Hence, a distinctive turning point of accelerated wage growth does not exist.

Table 1 summarizes a set of changing labor market conditions during the development process derived from the Lewis and neoclassical models. These predictions on wage growth

\footnotetext{
${ }^{5}$ Before the economy reaches the turning point, real wages might increase as a result of changes in the institutional wage due to nonmarket forces (Reynolds, 1965) or improvement in agricultural productivity. In this extended version of classical theory, the turning point signals the acceleration of real wage increase.

${ }^{6}$ Minami (1968) provides statistical tests showing that Japan reached the Lewis turning point between 1950-1960.
} 
Table 1: Predictions of Labor Market Conditions: Classical vs. Neoclassical Models

\begin{tabular}{|c|c|c|c|c|}
\hline \multirow{2}{*}{\multicolumn{5}{|c|}{$\begin{array}{l}\text { MPL } \\
\text { The Classical Lewis Model }\end{array}$}} \\
\hline & & & & \\
\hline \multicolumn{5}{|c|}{ Agriculture } \\
\hline Phase one & $M P L_{t}^{A}=0$ & 0 & $w_{t}^{A}=w^{*}$ & 0 \\
\hline Phase two & $0<M P L_{t}^{A} \leq w^{*}$ & positive & $w_{t}^{A}=w^{*}$ & 0 \\
\hline Phase three & $M P L_{t}^{A}>w^{*}$ & positive & $w_{t}^{A}=M P L_{t}^{A}$ & positive \\
\hline \multicolumn{5}{|l|}{ Industry } \\
\hline Phase one & $M P L_{t}^{M}=w$ & 0 & $w_{t}^{M}=w$ & 0 \\
\hline Phase two & $M P L_{t}^{M}>w$ & positive & $w_{t}^{M}=w^{*} q_{t}^{\dagger}>w$ & positive \\
\hline Phase three & $M P L_{t}^{M}>w$ & positive & $w_{t}^{M}=w_{t}^{A} q_{t}>w$ & positive \\
\hline \multirow{2}{*}{\multicolumn{5}{|c|}{$\begin{array}{l}\text { The Neoclassical Model } \\
\text { Aoriculture }\end{array}$}} \\
\hline Agriculture & & & & \\
\hline \multirow{2}{*}{ Industry } & $M P L_{t}^{A}>0$ & positive & $w_{t}^{A}=\mu w_{t}^{M}$ & positive \\
\hline & $M P L_{t}^{M}>0$ & positive & $w_{t}^{M}=M P L_{t}^{M}$ & positive \\
\hline
\end{tabular}

$w^{*}$ is the institutional wage measured in agricultural goods.

$w$ is the institutional wage measured in manufacturing goods at initial terms of trade.

${ }^{\dagger} q_{t}$ is the terms of trade between agriculture and industry.

can be tested empirically using data from a developing economy.

\subsection{Other Aspects of the Neoclassical Theory}

A major contribution of Schultz's Transforming Traditional Agriculture (1964) is his eloquent criticism of the "zero marginal product" hypothesis. He shows that agricultural output dropped significantly following heavy losses of rural manpower after the 1918-1919 influenza epidemics in India. Schultz argues forcefully that "there are comparatively few significant inefficiencies in the allocation of the factors of production in traditional agriculture."

The neoclassical framework stresses the role of individual choices and market equilibrating forces. A number of studies have provided empirical evidence on the price responsiveness of farmers in developing countries, which are shown to be consistent with the neoclassical competitive framework. Hansen (1969) presents evidence that male adults by and large are fully employed in rural Egypt once nonagricultural work is considered. Hansen also finds no evidence that wage level is governed by institutional factors. Instead, wages generally appear to be highly flexible and react to changes in demand. Huffman (1980) argues that farmers respond to changes in wage by reallocating labor between farm and nonfarm work. Empirical analysis based on county-level data from the 1964 US Census of Agriculture finds wage elasticity of labor supply to be 0.34 , well below the infinite wage elasticity predicted 
by the surplus labor hypothesis. Rosenzweig (1980) directly tests a neoclassical household labor supply model using micro data from India. By extending the theory to consider the differences in landholding status, Rosenzweig provides empirical evidence supportive of the neoclassical-competitive labor supply model and inconsistent with the labor surplus hypothesis. Since these early studies, a large body of literature has provided empirical support to the neoclassical theory of economic development (e.g., Rosenzweig, 1988).

\section{Empirical Analysis}

Based on Table 1, we conclude that the classical and neoclassical theories have different views on the development of a dual economy. In particular, they imply different patterns of wage growth across rural and urban sectors. The classical model predicts three stages of wage growth: an initial stagnation, followed by modest earnings increases in the urban sector, and lastly nationwide accelerated wage growth. In contrast, the neoclassical theory predicts continued wage growth across the two sectors during the development process.

In this section, we test the above mentioned implications of the two theories using multiple sources of aggregate and individual data. After rejecting the Lewis hypothesis, we proceed to examine whether the Chinese labor market data are consistent with other major implications of the neoclassical model. We will explore the role of individual choices and market forces in the determination of nonfarm work, rural-urban migration, interprovincial labor mobility, and returns to education.

\subsection{The Dual Economy and Labor Market Reforms in China}

Before the inception of reforms in 1978, there were massive distortions in the allocation of resources in China's centrally planned system. The cumulative effects of pursuing a heavy industry-oriented development strategy since the 1950s resulted in excessive allocation of capital assets in urban areas and a high percentage of the labor force concentrated in the countryside. The segregation of rural and urban sectors in China represents a typical dual economy. Within the rural sector, national policies during central planning stressed agricultural production and local grain self-sufficiency. Before the reforms, rural industrial activities concentrated on a narrow range of products and remained subsidiary to agriculture. In 1978, only about $7 \%$ of the rural labor force nationwide was in nonagricultural employment, generating approximately $7 \%$ of rural household earnings (Yang, 2004), a level far below that of other comparable developing countries.

Market-oriented development in rural China started with a household responsibility sys- 
tem. This reform replaced production teams with households as units of basic production. The change from communes to a household-based farm system induced strong family work effort, thus reducing the demand for workers in small Chinese farms. Therefore, farmers not only had incentives but also certain freedom in relocating labor to nonfarm uses. The catalyst for the rapid expansion of nonfarm production was a series of policies that loosened the restrictions on labor mobility and the operation of rural enterprises (Yang, 2004). By the mid-1980s, households were conscious of their alternative opportunities; and they had incentives to allocate resources quickly, including their labor, to nonagricultural activities that would generate higher returns than those from farming.

Prior to the recent tide of out-migration from agriculture, rural and urban labor markets were isolated in China for decades. Such segregation was mainly implemented through a Household Registration System (HRS; hukou system). HRS imposed strong restrictions on individuals in changing the location of their permanent residence. A rural worker would have serious difficulties in living in an urban area without an urban hukou because employment and the allocation of housing, food, and other necessities were all contingent on urban registration. Although rural reforms created the potential to release millions of rural workers from the agricultural sector, rural-to-urban migration was tightly controlled until the mid-1980s. Since then, the government permitted and then promoted rural nonagricultural activities, creating rural nonfarm jobs as a prelude to large scale rural-to-urban migration. Since the late 1980s, the growth of employment in rural nonfarm activities has slowed down significantly (Fleisher and Yang, 2008). Subsequently, a change in the residential registration law in 1988 made it easier for migrants to acquire legal temporary residence in urban areas. Beginning in the late 1980s, the demand for rural labor in urban areas continued to increase due to the development of urban private and informal sectors; thus, national and local authorities began to loosen restrictions on rural-to-urban migration (e.g. Fleisher and Yang, 2008; Cai et al., 2008). As a result, the number of rural migrant workers in urban areas began to increase dramatically. As labor mobility restrictions were lifted, rural households responsively allocated their labor among farm work, rural nonagricultural activities, and urban jobs to maximize earnings.

\subsection{Earnings Growth in Rural and Urban Sectors \\ Evidence from Aggregate Statistics}

Major labor market reforms in China have taken place along with profound socioeconomic transformations, including massive privatization, industrial structural changes, and regional development since the inception of reforms in 1978. China's wage structures have evolved 
accordingly, exhibiting major changes over the past three decades. In this section, we first provide a summary of the trends in average earnings for rural and urban individuals for the 1978-2008 period using published aggregate statistics.

Ideally, we would like to trace wage changes over time for comparable rural and urban workers. However, published aggregate statistics from the SYC only report labor earnings for staff and workers (zhigong), which are "formal employment" in the urban area. ${ }^{7}$ By definition, staff and workers do not include individuals employed in informal urban units, where rural migrant workers are heavily concentrated. Therefore, the labor earnings of staff and workers would match poorly with the wages of rural migrants. Although SYC reports per capita income from wages and salaries for rural households, converting this variable to a wage measure for rural workers is difficult. There are even more serious challenge in distinguishing the wages of workers of township and village enterprises (TVEs) from those of nonfarm self-employed or farm workers. Therefore, we can hardly construct comparable wage measures for workers across the two sectors from published aggregate statistics.

Nevertheless, SYC publishes per capita disposable income for rural and urban households. It is a comparable earnings variable across the two sectors, and presumably income growth is highly correlated with wage growth. Figure 1 presents the real per capita income series for the 1978-2008 period with all nominal incomes deflated by sector-specific CPI. ${ }^{8}$ Our main interest is on earnings growth over time; thus, we construct and plot income indices in the figure, setting the value of income in 1978 to 100 in each sector.

Between 1978 and 2008, average real per capita income of urban households grew more than sevenfold; similarly, that of rural households increased by about sixfold, as shown in Figure 1. The data reveal a striking feature: rural and urban earnings increased continuously and rapidly in lockstep throughout the 30-year period. This pattern rejects the applicability of the Lewis turning point to this time period in China because the hypothesis predicts the stagnation of rural wage growth in the first and second phases of development, followed by sharp wage increases in the third phrase. There is no clear evidence that China has

\footnotetext{
${ }^{7}$ Staff and workers comprise all laborers receiving payments and being employed by (a) state-owned units, (b) urban collectively owned units, (c) joint operation units, (d) limited liability companies and stock companies, (e) foreign-owned units, (f) units with investment from persons in Hong Kong, Macao, or Taiwan, or $(\mathrm{g})$ units subordinate to one or more of the above units. Hence, the term staff and workers exclude persons (a) employed in township and village enterprises, (b) working in individual/private enterprises, (c) urban self-employed persons, (d) retirees, (e) re-employed retirees, (f) teachers working in informal schools, (g) foreigners and persons from Hong Kong, Macao and Taiwan who work in urban units, and (h) other persons not to be included by relevant regulations.

${ }^{8}$ Disposable income of urban households is reported as the sum of wages and salaries, incomes from properties, net business earnings, and transfers from other household members minus income taxes and personal contributions to social security. Net income of rural households refers to the total income of wages and salaries, household operations, transfers, and property earnings minus taxes and fees, household operation expenses, depreciation of fixed assets for production, and gifts to relatives.
} 
experienced a long period of wage stagnation since the end of 1970s. Instead, the evidence supports the neoclassical predictions of coordinated and continued wage growth across rural and urban sectors during development. One driving force behind the synchronized income growth is the rapid expansion of rural to urban migration. Sheng (2008) estimates that the number of rural migrants increased from 8 million in 1985 to more than 120 million in 2005. Without this massive migration flow, there could be serious misalignment in the average wage growth of the two sectors. ${ }^{9}$

Figure 1: Per Capita Urban and Rural Real Income Growth, 1978-2008

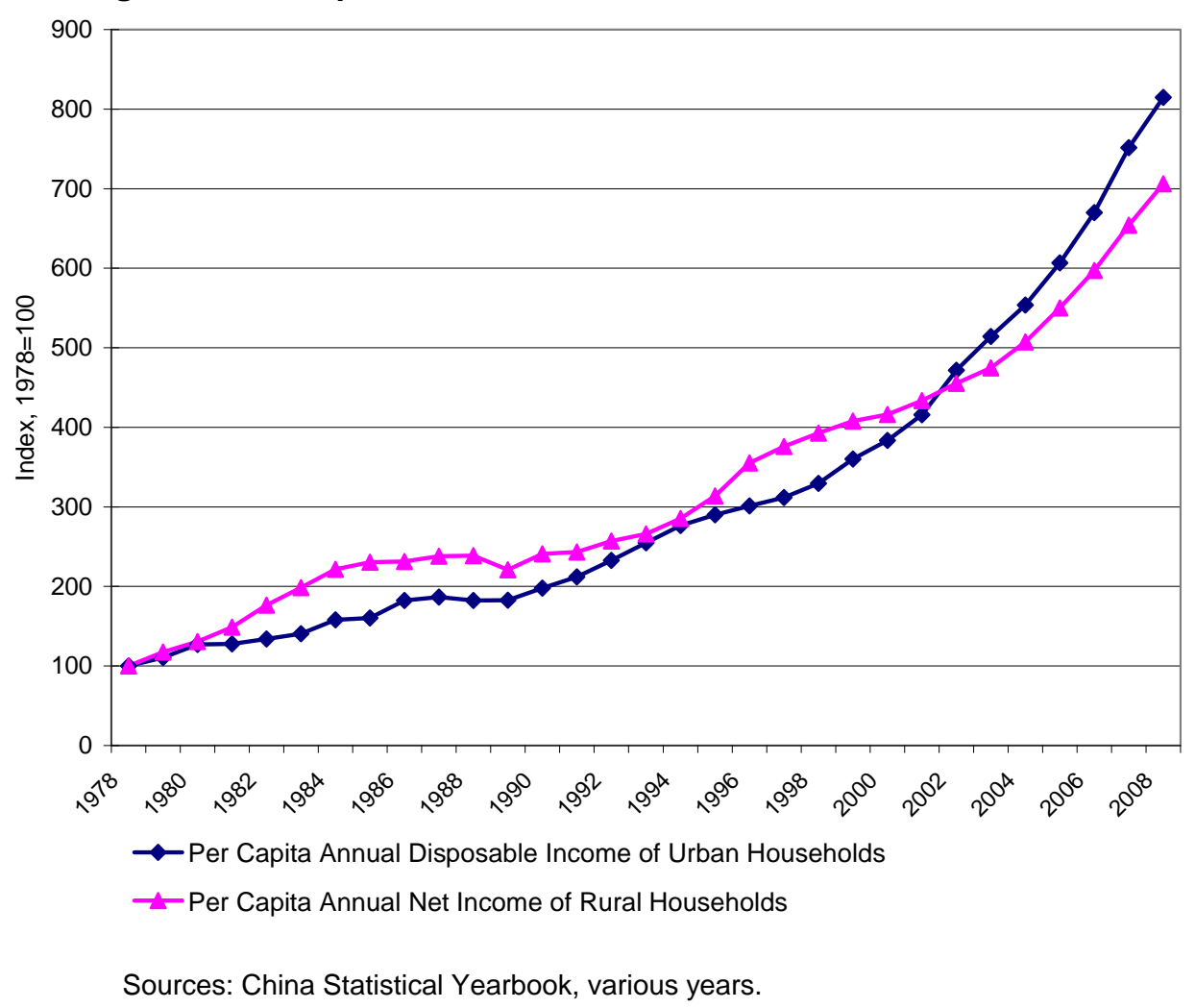

Income growth has been affected by macroeconomic environments and the progress of institutional reforms. The two indices of earnings growth reflect three distinctive phases of reforms. In the late 1970s, major economic reforms, such as the Household Responsibility System, were first introduced in the rural sector, resulting in rapid increases in farmers' earnings. Between 1978 and 1985, rural per capital real income increased at an annual rate of $12.7 \%$, surpassing the rate of $7.0 \%$ in the urban sector, because major urban reforms did not start until 1985. ${ }^{10}$ In the 1986-1997 period, rural reforms slowed down along with its

\footnotetext{
${ }^{9}$ Admittedly, there has been large and persistent rural-urban income disparity in China due to the continuation of urban-biased institutions and policies from the central planning period (Yang, 1999). However, many barriers to labor mobility have been removed during the reform era.

${ }^{10}$ During this period, the urban-rural per capita income ratio was reduced from 2.9 to 2.0 , the lowest level in the past three decades.
} 
earnings growth, declining to an annual rate of $4.2 \%$. During the same period, employment in private and jointly-owned units experienced vigorous growth in the urban area, although total urban income growth was still at a modest rate of $5.7 \%$, which was partly influenced by the two consecutive years of negative growth in 1988 and 1989 because of high inflation and political upheaval. In 1998-2008, earnings growth accelerated in both sectors, reaching 5.9\% and $9.1 \%$ in rural and urban areas, respectively. This period of rapid income growth has coincided with China's preparation for and accession into the WTO, major restructuring of SOEs that began in 1998, government direct subsidies to farmers, and the removal of agricultural taxes in recent years.

Two caveats concerning the limitation of aggregate data are in order. First, per capita income includes not only wages and salaries but also incomes from business, properties, and transfers. Therefore, it is the average income for the population, not a direct measure of labor earnings or payment to labor services. Second, aggregate data do not have information on individual characteristics. The educational attainment of workers may be distributed unevenly across rural and urban areas; thus, direct tests of the Lewis and neoclassical theories should focus on the wage changes of workers with low education across sectors and over time.

\section{Evidence from Micro Data}

We use the CHNS as the primary source of microeconomic data to analyze the changes in real wages over time. The survey was conducted by an international team of researchers whose backgrounds include nutrition, public health, economics, sociology, Chinese studies, and demography. The survey covers nine provinces: Liaoning, Heilongjiang, Jiangsu, Shandong, Henan, Hubei, Hunan, Guangxi, and Guizhou. A multistage, random cluster process was used to draw the samples surveyed in each of the provinces, covering both rural and urban areas. For the rural sample, counties in the nine provinces were stratified by income (i.e., low, middle, and high), and a weighted sampling scheme was used to select four counties in each province randomly. For the urban sample, the provincial capital and a lower income city were selected. Villages and townships within the counties and urban and suburban neighborhoods within the cities were selected randomly. There are about 4,400 households in the overall survey, covering about 19,000 individuals. The first round of the CHNS was collected in 1989, and six additional panels were collected in 1991, 1993, 1997, 2000, 2004, and 2006. This paper uses data from the CHNS longitudinal master files covering all survey years. Liaoning was not able to participate the survey in 1997, and Heilongjiang was only added to the survey in 1997. To keep our empirical analysis comparable over time, we exclude Liaoning and Heilongjiang and restrict our sample to the remaining seven provinces.

Throughout the paper, we focus on wages for adult workers engaged in wage employment. 
Table 2: Sample Statistics from CHNS, 1989-2006

\begin{tabular}{lcccccccc}
\hline Year & $\mathrm{N}$ & $\begin{array}{c}\text { Earnings } \\
(2007 \text { yuan })\end{array}$ & \% Male & Age & $\begin{array}{c}\text { Years of } \\
\text { School }\end{array}$ & $\begin{array}{c}\text { \% Middle } \\
\text { school }\end{array}$ & $\begin{array}{c}\text { \% High } \\
\text { school }\end{array}$ & \% College \\
\hline Urban sites & & & & & & & & \\
1989 & 1260 & 3843 & 55.6 & 34.9 & 8.3 & 63.6 & 29.6 & 6.8 \\
1991 & 1164 & 3963 & 54.9 & 35.1 & 9.0 & 60.1 & 32.6 & 7.4 \\
1993 & 993 & 5100 & 55.3 & 36.2 & 9.2 & 58.7 & 33.0 & 8.3 \\
1997 & 1071 & 6676 & 54.4 & 37.7 & 9.7 & 50.3 & 38.6 & 11.1 \\
2000 & 916 & 9707 & 56.1 & 38.3 & 10.2 & 41.8 & 43.7 & 14.5 \\
2004 & 665 & 13600 & 57.3 & 40.0 & 10.9 & 35.2 & 46.0 & 18.8 \\
2006 & 678 & 17094 & 58.8 & 40.7 & 11.2 & 34.2 & 42.2 & 23.6 \\
\hline Rural sites & & & & & & & \\
1989 & 1267 & 3782 & 62.3 & 33.5 & 7.8 & 74.7 & 23.0 & 2.3 \\
1991 & 1153 & 3529 & 61.7 & 33.7 & 8.5 & 72.1 & 25.5 & 2.4 \\
1993 & 1082 & 4148 & 63.0 & 34.1 & 8.7 & 69.9 & 27.7 & 2.4 \\
1997 & 1111 & 5987 & 61.5 & 34.4 & 8.9 & 66.9 & 29.5 & 3.6 \\
2000 & 1049 & 8870 & 62.3 & 34.3 & 9.4 & 60.0 & 33.5 & 6.6 \\
2004 & 615 & 10777 & 63.7 & 38.2 & 10.0 & 51.9 & 40.7 & 7.5 \\
2006 & 710 & 13310 & 62.5 & 39.6 & 10.2 & 49.0 & 39.2 & 11.8 \\
\hline
\end{tabular}

Annual wage income is computed as months worked times average monthly non-retirement wage, plus bonuses and other cash or in-kind income. We deflate annual wages to 2007 by province-specific consumption price indices. Our sample for analysis includes all workers aged 16-55 for females and 16-60 for males, excluding employers, self-employed individuals, independent operator (including farmers), students, and workers whose real annual wages were below one half of the real minimum wage. ${ }^{11}$ Finally, we exclude individuals with invalid data on educational attainment. Applying the above selection criteria yields 13,734 workers engaged in wage employment for the seven survey years. Among these workers, 6,747 (49.1 percent) are from urban sites (14 cities), and 6,987 (50.9 percent) are from rural sites (28 counties).

Table 2 presents summary statistics on wage and worker characteristics for each wave of the CHNS surveys. The top panel describes sample statistics for workers from the urban sites, the bottom panel denotes the workers from the rural sites. Table 2 reveals three noticeable trends. First, workers from urban sites earn higher wages than those from rural sites. The urban-rural wage differential increased from $2 \%$ to $28 \%$ in $1989-2006$. However, the rural-urban wage disparity is much lower than the per capita income gap observed from the aggregate data. This partly reflects the fact that rural agricultural workers still earn a

\footnotetext{
${ }^{11}$ Provincial-level minimum wage is collected from the provincial or municipal Ministry of Human Resources and Social Security. The minimum wage restriction has little effect on the sample average wage.
} 
much lower income than rural non-agricultural workers in wage employment.

Second, the trends in urban and rural wage growth based on CHNS data correspond closely to patterns of per capita income growth in Figure 1 based on aggregate data. In both rural and urban regions, real wage barely changed from 1989 to 1991 because of contractional macroeconomic policies and high inflation. Between 1991 and 2006, real wages grew continuously at an annual rate of $10.2 \%$ and $9.3 \%$ in urban and rural sites, respectively. From household data, we do not observe wage stagnation in either urban or rural area, at least since the late 1980s. Again, evidence appears to reject the existence of the Lewis turning point.

Finally, Table 2 reports differences in individual characteristics among wage earners across rural and urban sites. Workers from rural sites have a higher percentage of males; they are slightly younger and less educated than their urban counterparts. While educational attainment increased over time for all workers, urban workers continued to have an advantage. In particular, the difference in average education between rural and urban workers was 0.5 year in 1989, but the gap increased to 1 year in 2006. In 2006, $49 \%$ of workers from rural sites had an education level of middle school and below, which was 14.8 percentage points higher than those from urban sites. In contrast, $23.6 \%$ of urban workers had at least some college education, whereas only $11.8 \%$ of rural workers had the same schooling. These observed schooling differences are likely to be a main source of the observed rural-urban wage differential.

Figure 2 presents the relative wages and wage growth for different groups of workers. The real wages in 1989 are standardized to 100 . We plot the patterns of wage growth for all workers and for those with middle-school education and below for both urban and rural samples. As the figure shows, wages for all workers increased substantially at a rate greater than that of workers with middle-school education and below, indicating growing returns to education during this time period. Although wage growth for the less educated workers is below that of the full sample ( $7.4 \%$ vs. $9.2 \%$ in urban sites and $6.6 \%$ vs. $7.7 \%$ in rural sites), their wages have grown continuously since the early 1990s, evidence inconsistent with the Lewis model.

During the process of out-migration from agriculture, rural individuals can choose among rural farm work, rural nonfarm work, and labor migration to cities. Although nonfarm work and migration yield a monetary premium, they also involve psychological and transportation costs (Zhao, 1999). One unique feature of the CHNS data is that the survey not only samples households from rural and urban sites but also records the status of each individual's household registration (hukou) beginning 1993. Using information on household registration, we can classify workers into three categories: rural workers employed in nonfarm activities, 
rural migrant workers approximated by those working in urban sites with rural registration, and urban workers with urban registration. ${ }^{12}$ Table 3 compares the wages of three types of workers with middle-school education or below and presents their wage growth by setting the 1993 wage levels as 100.

Figure 2: Urban and Rural Real Annual Wage Growth, 1989-2006

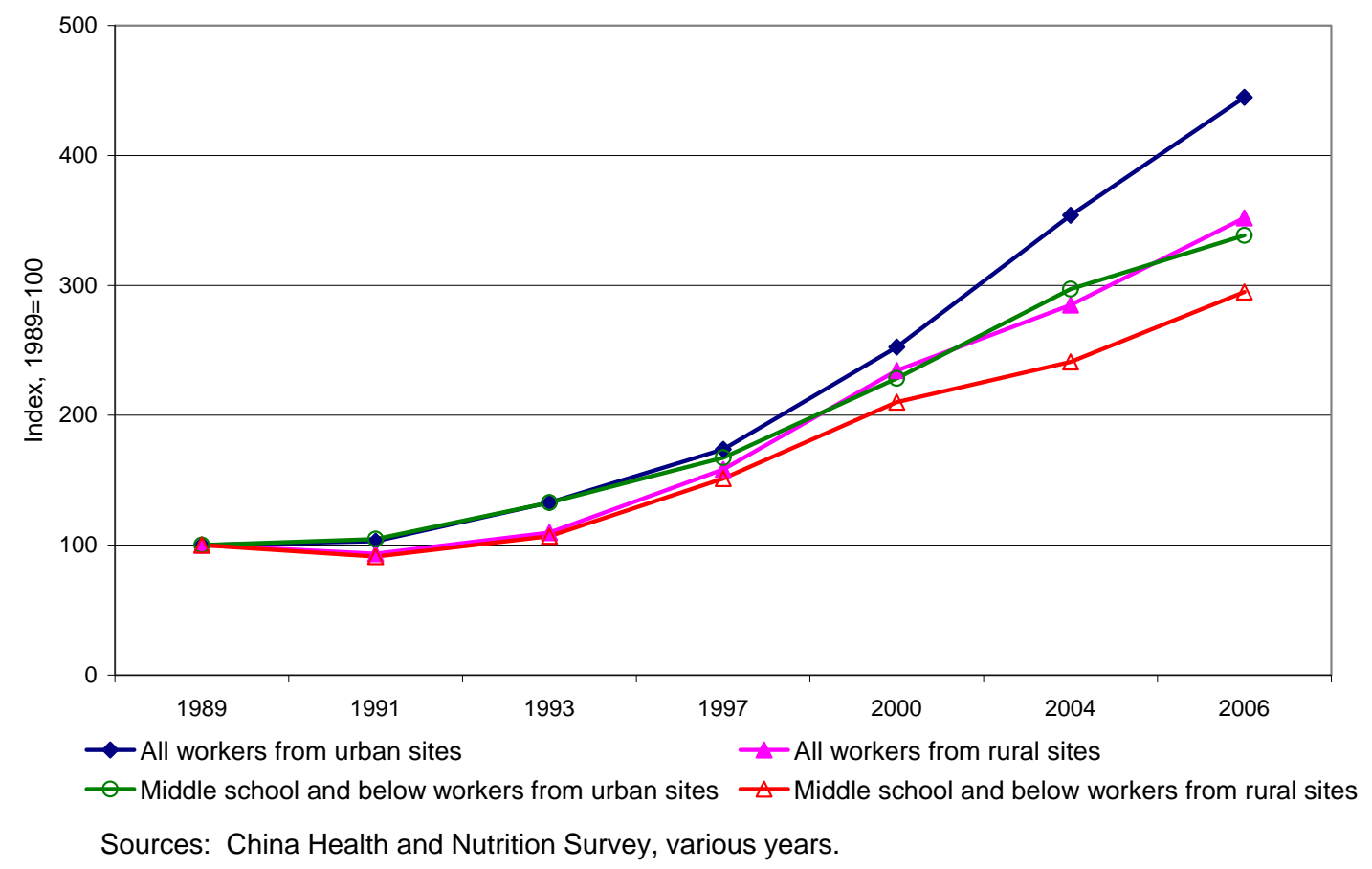

Table 3 establishes a clear trend that the real wages of rural nonfarm workers, rural migrant workers, and urban workers with limited education all experienced continuous growth in the 1993-2006 period. These facts are inconsistent with the Lewis model of stagnant wage growth followed by sharp rises in earnings. After 2000, wage growth of rural migrant workers had outpaced that of rural nonfarm workers. This is consistent with the findings of Zhao (1999): due to rising migration cost, rural workers may choose rural nonfarm jobs over migration even at significantly lower wages. Since 2000, average wages of rural migrant workers are below those of comparable urban workers, but t-tests show that the two wage levels are not statistically different. This finding may seem surprising because the earnings of urban residents are known to be higher than those of rural migrants in urban China (Meng and Zhang, 2001). However, a recent study by Démurger et al. (2009) adopts a careful decomposition analysis and finds that the differences in observed characteristics between the two

\footnotetext{
${ }^{12}$ In CHNS, urban sites include both city neighborhoods and suburban villages, whereas rural sites include township and rural villages. Since we exclude owner-employers and self-employed operators (including farmers) from the sample, workers in rural sites with rural registration are most likely working in township and village enterprises or rural private enterprises. Workers in urban sites with rural registration can be rural migrant workers or workers from local suburban villages, which we do not attempt to separate.
} 
Table 3: Real Wages of Different Groups of Low-Skilled Workers

\begin{tabular}{lcccccc}
\hline & \multicolumn{2}{c}{ Rural Nonfarm Workers* } & \multicolumn{2}{c}{ Rural Migrant Workers } & \multicolumn{2}{c}{ Urban Workers } \\
\cline { 2 - 7 } & Wage & Growth & Wage & Growth & Wage & Growth \\
\hline 1993 & 4244 & 100.0 & 5131 & 100.0 & 4521 & 100.0 \\
& $(2578)$ & & $(3953)$ & & $(4253)$ & \\
1997 & 5971 & 140.7 & 6140 & 119.7 & 6038 & 133.6 \\
& $(3432)$ & & $(4612)$ & & $(5233)$ & \\
2000 & 8193 & 193.0 & 7254 & 141.4 & 8578 & 189.7 \\
& $(6608)$ & & $(4048)$ & & $(9033)$ & \\
2004 & 8375 & 197.3 & 9923 & 193.4 & 11259 & 249.0 \\
& $(9450)$ & & $(13264)$ & & $(11608)$ & \\
2006 & 10208 & 240.5 & 11200 & 218.3 & 13555 & 299.8 \\
& $(6412)$ & & $(7324)$ & & $(17889)$ & \\
\hline
\end{tabular}

${ }^{*}$ All wages are measured in 2007 yuan. Standard deviations are in parentheses.

groups of workers have the strongest effect on their earnings differences. Table 3 suggests that the wages of rural migrant workers are competitive to the wages of urban unskilled workers with similar characteristics and that these two groups of workers appear to be close substitutes in the urban labor market. These findings lend support to the neoclassical view of competitive forces in the Chinese labor market.

\subsection{Migration and Labor Market Development}

\section{Rural Labor Markets and Rural-Urban Migration}

During the centrally planned regime, labor mobility was restricted by the household registration system and a food rationing system. Beginning in the late 1970s, regulations governing occupational choice and internal migration were gradually relaxed. In the early 1980s, the government began to encourage farmers to leave agricultural production. A major policy reform took place in 1988, when the control over labor flows was officially relaxed (Yang and Zhou, 1999). Farmers were allowed to move to cities if they could provide their own staples and were financially capable of running a business. On the supply side, the adoption of the household responsibility system gave rural households the freedom of allocating productive resources, including labor. On the demand side, the development of TVEs and urban private and informal sectors increased the demand for rural labor.

Consistent with the neoclassical theory of rational behavior, farm households reacted to these policy changes in a responsive manner. Starting in the mid-1980s, a large number of rural workers began to seek employment in rural off-farm work. Figure 3 shows the employment shares of rural agricultural workers, workers in TVEs, and workers in rural 
private and individual enterprises. In the late $1970 \mathrm{~s}$, more than $90 \%$ of rural employment was engaged in agricultural work. The proportion of rural workers in agriculture started its long-term decline in 1984 when the government encouraged farmers to leave agricultural production and work in nearby small towns. By 2008, the percentage of rural employment in agriculture already dropped below $60 \%$. The share of TVE workers rose from $10 \%$ in 1978 to more than $30 \%$ in 2008 . Today, more than $10 \%$ of rural workers are employed in rural private and individual enterprises, an ownership form that was nonexistent in the early years of reform.

Figure 3: Distribution of Rural Employment, 1978-2008

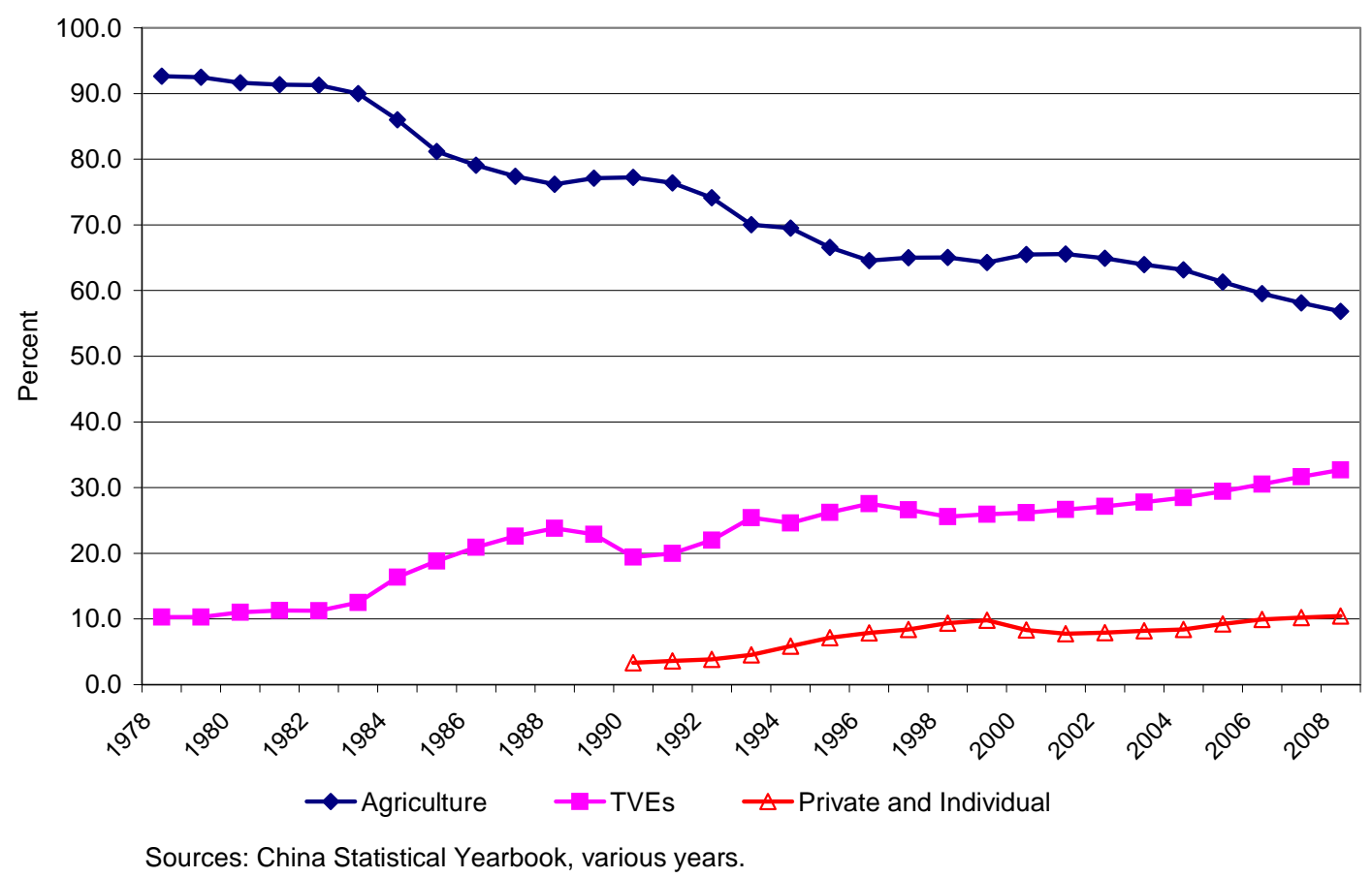

After the deregulation on rural-urban migration in the late 1980s, the size of rural migrants in cities increased rapidly. Rozelle et al. (2009) estimated that 154 million rural individuals worked off-farm in 1995, including 54 million long-term migrants. Migration has become the most prevalent form of labor supply to off-farm activities since the late 1990s. Rural to urban migration has exploded in recent years. Sheng (2008) estimates that the number of migrants reached more than 120 million in 2005. The expansion of rural off-farm work and rural-urban migration has played a critical role in facilitating the integration of rural and urban labor markets in China.

Aside from the documentation on the growing number of off-farm workers and rural migrants, there are also extensive micro evidence on farmers' optimal choices among agricultural work, local nonfarm work, and migration. Between 1984 and 1987, the total grain 
output in China stagnated after a period of enormous growth. This was attributable to the exodus of agricultural labor to rural industrial activities, evidence indicating positive marginal product of labor in the agricultural sector even in the very early years of reform (Lin, 1992). As corroborative evidence, Yang (2004) finds that farm households quickly reallocated labor and capital from agricultural to nonagricultural activities once mobility controls were relaxed. Moreover, Yang (1997) and De Brauw et al. (2002), among others, show that education facilitates farmers to participate in nonfarm work and migration. These findings are consistent with the neoclassical view of optimizing individuals and the existence of market equilibrating forces.

\section{Interprovincial Migration}

Another aspect of the neoclassical framework of development emphasizes individual migration behavior in the context of spacial equilibrium. For instance, Todaro (1969) highlights the importance of rural-urban "expected" income differential, that is the sectoral income gap adjusted for urban unemployment, as a major factor influencing migration decision. Econometric results from Zhu (2002) show that rural-urban income gaps significantly influence individual mobility decisions in China. Persistent income gaps exist not only across rural and urban areas, but also among geographic regions. In 2005, for example, the national average wage of staff and workers was 18,364 yuan; the highest level was observed in Shanghai at 34,345 yuan, whereas the lowest was in Jiangxi at 13,688 yuan. With a competitive and well-functioning labor market in the US, Topel (1986) finds that migration flows are responsive to regional conditions. Kennan and Walker (2009) develop and estimate a model of optimal sequence of migration decisions and find that interstate migration choices are substantially influenced by alternative income prospects. We are interested in examining whether similar market forces are at work in China.

Using provincial level data, we test the responsiveness of migration decisions to expected earnings differentials and unemployment rates across Chinese regions. The hypothesis is that inward migration flows respond positively to expected earnings in the destination province and negatively to unemployment rates in that location. The responsiveness of labor mobility to market conditions is an important indicator of a well-functioning labor market.

Provincial migration flows in this study are drawn from Duan et al. (2008). Their data are compiled from the 1990 and 2000 censuses and the 1987 and $20051 \%$ population surveys. Inward migration flow to each province is measured as a percentage of national total migration. To capture regional differences in expected earnings, we collect data on average wages of staff and workers and urban unemployment rate in each province from various volumes of SYCs and Labor Statistical Yearbooks. Table 4 presents the sample statistics of our 
Table 4: Sample Statistics of the Province Panel

\begin{tabular}{cccc}
\hline & $\begin{array}{c}\text { Migration }(M) \\
(\%)\end{array}$ & $\begin{array}{c}\text { Average Wage }(E) \\
\text { (Yuan) }\end{array}$ & $\begin{array}{c}\text { Unemployment Rate }(U) \\
(\%)\end{array}$ \\
\hline 1987 & 3.6 & 1,488 & 2.2 \\
& $(2.2)$ & $(197)$ & $(1.2)$ \\
1990 & 3.5 & 2,163 & 2.8 \\
& $(2.4)$ & $(315)$ & $(1.3)$ \\
2000 & 3.5 & 9,399 & 3.1 \\
& $(3.7)$ & $(2,930)$ & $(0.7)$ \\
2005 & 3.5 & 18,131 & 3.9 \\
& $(4.2)$ & $(5,613)$ & $(0.7)$ \\
\hline
\end{tabular}

Standard deviations are in the parentheses.

provincial panel. We use data from 28 provinces for 4 years; Chongqin, Hainan, and Tibet are excluded from the sample because of missing observations.

We estimate the following migration equation:

$$
M_{i t}=\alpha_{0}+\alpha_{1} E_{i t}+\alpha_{2} U_{i t}+u_{i t},
$$

where $M_{i t}$ denotes the share of inflow migration in province $i$ in year $t, E_{i t}$ is the average wage in the province measured in 10,000 yuan, $U_{i t}$ represents the urban unemployment rate, and $u_{i t}$ is an error term associated with idiosyncratic shocks in the local labor market. Column (1) of Table 5 reports the OLS estimates of Equation (1). Consistent with the hypothesis that individuals make migration decisions to maximize expected earnings, the provinces with higher wages and lower unemployment rate attract more migrants. Both of the estimated coefficients are statistically significant.

There are large differences in the cost of living across Chinese provinces that may affect migration decisions. As Brandt and Holz (2006) argue, regular provincial CPI indices only allow a comparison of consumer prices over time but not a comparison of absolute price levels between different provinces at a point in time. We use their spatial price indices to deflate nominal earnings and construct provincial real earnings $\left(R E_{i t}\right)$ with adjustments to local cost of living based on a basket of urban commodities ${ }^{13}$. In regression (2), with the replacement of nominal earnings by real earnings, we find similar positive effect of wage and negative effect of unemployment on migration inflows at the provincial level.

Migration flows may affect labor supply and therefore influence concurrent wages and unemployment rate in the local labor market. To mitigate this potential endogeneity, we

\footnotetext{
${ }^{13}$ We use the estimates of current cost of urban basket from Brandt and Holz (2006)'s online appendix. These price indices are available for 1984-2004. We use the indices in 2004 as proxies for 2005.
} 
Table 5: Impact of Expected Earnings on Migration

\begin{tabular}{|c|c|c|c|c|}
\hline Explanatory & Depender & variable $=$ & Migration & $\operatorname{ares} M_{i t}$ \\
\hline variable & (1) & (2) & (3) & (4) \\
\hline$E_{i t}$ & $\begin{array}{l}1.131^{* *} \\
(0.423)\end{array}$ & & & $\begin{array}{c}0.439^{*} \\
(0.269)\end{array}$ \\
\hline$U_{i t}$ & $\begin{array}{c}-0.932^{* *} \\
(0.268)\end{array}$ & $\begin{array}{c}-0.885^{* *} \\
(0.274)\end{array}$ & & $\begin{array}{c}-0.348^{*} \\
(0.210)\end{array}$ \\
\hline$R E_{i t}$ & & $\begin{array}{l}0.348^{* *} \\
(0.165)\end{array}$ & & \\
\hline$E_{i t-1}$ & & & $\begin{array}{l}1.247^{* *} \\
(0.479)\end{array}$ & \\
\hline$U_{i t-1}$ & & & $\begin{array}{c}-0.817^{* *} \\
(0.258)\end{array}$ & \\
\hline Constant & $\begin{array}{l}5.436^{* *} \\
(0.789)\end{array}$ & $\begin{array}{l}5.083^{* *} \\
(0.815)\end{array}$ & $\begin{array}{l}5.086^{* *} \\
(0.760)\end{array}$ & $\begin{array}{l}4.222^{* *} \\
(0.537)\end{array}$ \\
\hline Adjusted $R^{2}$ & 0.097 & 0.076 & 0.085 & 0.113 \\
\hline Sample size & 112 & 112 & 112 & 112 \\
\hline
\end{tabular}

replace current period wage and unemployment rate by those from the previous year in regression (3). Before their move, potential migrants form expectations about their future earnings based on observed local market conditions in potential destinations in the previous year. Their migration can affect the destination's labor market conditions after the moving decision has materialized but is not simultaneously determined with past conditions. Estimates of regression (3) show that migration has similar responses to current and lagged unemployment and wages.

The simple specification of Equation (1) has potentially left out other determinants of migration. These omitted variables, such as certain provincial characteristics, may affect migration flows, wages, and unemployment simultaneously. For instance, policy or geographic advantages of a coastal province may attract more migration inflows and result in high wages and low unemployment. With limited information on these variables but with the aim of controling for possible omitted variable bias, we run a fixed-effects regression and report the results in column (4) of Table 5. Although the magnitude of the coefficients is smaller than the other specifications, the signs of the key estimates remain and are still statistically significant.

These regression results suggest that the effect of expected earnings and unemployment on migration is robust to alternative specifications. The high level of earnings of a destination attracts inward migration, and a high rate of local unemployment discourages potential 
movers. Similar empirical results were found for the US economy where labor markets usually operate efficiently (e.g. Topel, 1986). Validating these results for China is encouraging because serious labor market distortions are believed to exist in the 1987-2005 period. These findings suggest that rational individual choices and market forces were already behind the integration of regional labor markets in China.

\section{Returns to Education}

Trends in monetary returns to education provide another criterion for evaluating the functionality of a labor market. Human capital theory postulates that investments in education have an effect in raising worker productivity, and this claim has been supported by strong empirical evidence worldwide. However, in a labor market with policy interventions and institutional distortions, schooling may not be properly rewarded. Estimates of average returns to education for China are typically around 4\%-5\% in the late 1980s and early 1990s for both rural (e.g., Yang, 1997) and urban regions (e.g., Meng and Zhang, 2001), much lower than the average schooling returns of about 10\%-11\% found in the rest of the world (Psacharopoulos, 1994). Therefore, the changes in returns to education can serve as a barometer to gauge the progress of reforms towards a competitive labor market.

Since the mid-1980s, major wage and employment reforms have taken place in urban China (Zhang et al., 2005). However, studies using data from the late 1980s and early 1990s continue to find a low rate of return to education. Among other studies, Meng and Kidd (1997) report the rates of returns to education at $2.5 \%$ and $2.7 \%$ in 1981 and 1987 among workers employed in state-owned enterprises, respectively. Maurer-Fazio (1999) finds $2.9 \%$ and $4.5 \%$ of returns for male and female workers in 1988, and these returns rose to $3.7 \%$ and $4.9 \%$ in 1992, respectively. Yang (2005) shows that average rates of returns to education

across a sample of cities increased from 3.1\% to $5.1 \%$ between 1988 and 1995 . Using the UHS data, Zhang et al. (2005) document continued increases in schooling returns in urban China from $4 \%$ in 1988 to $10.2 \%$ in 2001. For rural households, Li et al. (2005) reports rising returns to education in the years 1988, 1992, 1996, and 2002 based on a rural sample in northern Jiangsu. Similarly, Zhang et al. (2008) finds that the rate of returns to education rose to $7 \%$ for a national representative rural sample in 2004 .

To examine how market rewards to education have evolved with reforms, we update the estimates of schooling returns to recent years and compare the estimates with those from the mature US labor market in the same time period. The data for China come from 20 consecutive years of the UHS conducted by the National Bureau of Statistics from 1988 through 2007. The UHS data record basic conditions of urban households and detailed information on employment, wages, and demographic characteristics of all household members 
in each calendar year. Our data are from six provinces, namely, Beijing, Liaoning, Zhejiang, Sichuan, Guangdong, and Shaanxi, which are representative of China's regional variations. We focus on annual wages for adult workers engaged in wage employment. Wage income consists of basic wage, bonus, subsidies, and other labor-related earnings from a regular job. Our sample includes all workers aged 16-55 for females and 16-60 for males, excluding employers, self-employed individuals, farm workers, retirees, students, and those re-employed after retirement. Consistent with standard labor market studies, we exclude workers whose real annual wages are below one-half of the real minimum wage to assure that workers in the sample have full labor market engagements. In total, our data cover 250,006 individuals in the period of 1988-2007. In the 1988-1991 period, annual sample size is about 3,000 individuals, whereas the sample size increases to about 8,500 in 1992-2001, and rises further to about 25,500 individuals per year since 2002 .

We estimate a standard Mincer-type earnings equation for each year:

$$
\ln w_{i}=\beta_{o}+\beta_{s} S_{i}+\beta_{1} X_{i}+\beta_{2} X_{i}^{2}+\beta_{3} G_{i}+\mathbf{R}_{i} \boldsymbol{\beta}_{t}+\varepsilon_{i}
$$

where $w_{i}$ is annual wage earnings of individual $i, S_{i}$ is the years of schooling, $X_{i}$ is the years of potential experience measured as min (age - $S_{i}-6$, age - 16), and the quadratic experience term $X_{i}^{2}$ allows for a concave lifetime wage profile. The variable $G_{i}$ denotes a dummy variable for male, and $\mathbf{R}_{i}$ is a set of provincial dummy variables. Ideally, we would use hourly wages in the regression, but work hours are not reported in the UHS data before 2002. From this specification, the schooling coefficient $\beta_{s}$ provides an estimate for the rate of returns to education.

Figure 4 plots year-specific OLS estimates of the rates of returns to education in urban China. ${ }^{14}$ The rate of return to one additional year of schooling increases from $3.6 \%$ in 1988 to $11.4 \%$ in 2007 . Whereas the schooling coefficient rises continuously until 2004 , it stabilizes to around $11 \%$ since then. These results extend the empirical findings of Zhang et al. (2005) to recent years.

To compare the market value of schooling in China with that of a mature labor market, we estimate the same Mincer earnings function for the US during the same period. The US data come from 20 consecutive years of March Current Population Survey (CPS) conducted by the US Census Bureau, which is a monthly survey of about 60,000 households. It contains detailed information on employment, earnings, and demographics of all members of households. We apply the same sample restrictions as those for the Chinese data. The total number of individuals are 2,150,908 in the period of 1988-2007. The annual sample size is

\footnotetext{
${ }^{14}$ Detailed results of the regressions for all variables, including their standard errors and other statistics, are available from the authors.
} 
about 92,000 individuals in the 1988-2000 period, whereas the number increases to about 136,000 in 2001.

Figure 4: Rates of Return to Education in Urban China and U.S. 1988-2007

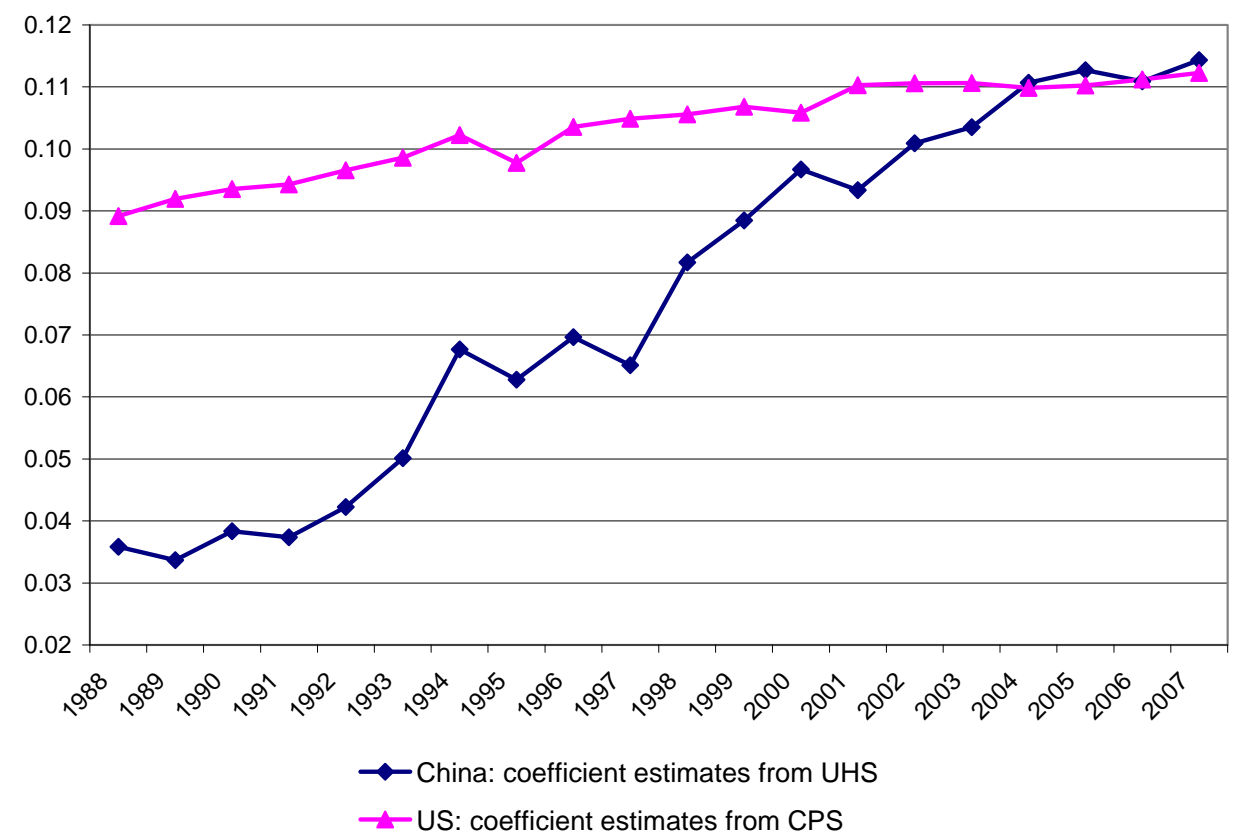

We estimate Equation (2) for each of the years using the US CPS data and plot the estimated coefficients of schooling returns along with the estimates for China in Figure $4 .^{15}$ Two striking patterns emerge from Figure 4. First, in the late 1980s and early 1990s, the rate of returns to education in China was just above one-third of the level found in the US. Second, whereas the returns to schooling in both economies experienced upward trends during the 20-year period, the growth was much faster in China. By 2004, the rate of returns to education in China had already converged to the US level, and the two series fluctuated together just above $11 \%$ thereafter. The US is used as a benchmark because its labor market is known to have few distortions. ${ }^{16}$ The rising returns to education in urban China and their convergence to the US level can be interpreted as evidence that the pricing of human capital has already approached the international norm. These findings suggest much improved labor market situations in recent years relative to the distorted wage determinations in the late 1980s.

\footnotetext{
${ }^{15}$ Additional variables of worker characteristics, such as race, marital status, party membership, and union status, can be added to the earnings regression. However, because these variables are not always comparable across the Chinese and the US samples, we adopt the very basic specification of the human capital earnings function.

${ }^{16}$ The underlying logics of this comparison is similar to that of Hsieh and Klenow (2009) who uses the US as a benchmark for studying the extent of input market distortions in China and India.
} 


\section{Conclusions}

Recent reports on labor shortages and rising wages of unskilled workers have caused public concerns over whether China can maintain its global labor advantage in manufacturing production and international trade. Applying the classical Lewis model of development, several existing studies have found accelerated wage growth for rural migrants in recent years, suggesting the arrival of the Lewis turning point. These studies anticipate that continued industrialization and economic growth will lead to even higher rate of wage growth in China.

In this paper, we have cast doubts on the applicability of the Lewis model for analyzing labor market developments in China. As such, we have laid out the basic ingredients of the neoclassical theory of development as an alternative framework. The implications of the two models on wage growth are derived and tested using multiple sources of data. We find that altough migrant wages have indeed increased fast in recent years, they are consistent with high GDP growth after China's entry into the WTO. There is no systematic evidence of institutional wage setting or zero marginal product of labor in rural China in the past three decades. Empirical evidence based on both aggregate and household data fails to support the arrival of the Lewis turning point in China, showing continuous and coordinated wage growth across rural and urban sectors during the post-reform era instead. Supporting the neoclassical view, we find that rural workers expanded off-farm work in a responsive manner, interprovincial migration reacted to expected earnings and local employment conditions, and the rates of returns to education converged to the international norm found in competitive labor markets. These findings suggest that the Chinese labor market has been responsive to changes in the demand and supply conditions and has become more efficient in the determination of wages. ${ }^{17}$

Despite major progress, institutional impediments to a well functioning labor market in China still remain. Household registration (hukou) and social security systems are two well-recognized areas that need refinements and further reforms. The lack of urban welfare and social security provisions, especially among informal employment of rural migrants, is an important piece of the puzzle behind the reported labor shortages and rising wages of unskilled labor along coastal regions. General improvements in living and working conditions in the countryside have also contributed to the observed outcomes. With the repeal of agricultural taxes, the removal of school tuitions and fees in poor rural regions and job

\footnotetext{
${ }^{17}$ In a related paper (Ge and Yang, 2010), we investigate wage growth and rising wage inequality in urban China for the 1992-2007 period, and find evidence that standard market forces, such as capital accumulation, export expansion and skill-biased technological change, are the main determinants of wages during the period of rapid globalization and transition.
} 
creations in the hinterland, plus the rising housing prices and other living costs in cities, wages must rise to attract rural migrants to stay in urban regions away from their homes. However, these market forces do not necessarily imply that wages in China will escalate at a much higher pace relative to the wage growth in the past several years, as the huge pool of labor will serve as a stabilizing force. As part of market responses, labor-intensive production may continue to relocate to inland regions where labor costs are much lower. Therefore, because China's manufacturing wage is still about $7 \%-10 \%$ of Korea and Japan and 18\%-21\% of Taiwan and Hong Kong (Yang et al., 2010), we believe that China will likely maintain its global labor advantage in the foreseeable future.

\section{References}

Brandt, L. and C. Holz (2006). Spatial price differences in China: estimates and implications. Economic Development and Cultural Change 55, 43-86.

Cai, F. and Y. Du (2010). Wages increase, wage convergence, and Lewis turning point in China. Working Paper, Institute of Population and Labor Economics, Chinese Academy of Social Sciences.

Cai, F., A. Park, and Y. Zhao (2008). The Chinese labor market in the reform era. In L. Brandt and T. Rawski (Eds.), China's Great Economic Transformation, pp. 167-214. Cambridge University Press.

Cai, F. and M. Wang (2010). Growth and structural changes in employment in transition China. Journal of Comparative Economics 38(1), 71-81.

De Brauw, A., J. Huang, S. Rozelle, L. Zhang, and Y. Zhang (2002). The evolution of China's rural labor markets during the reforms. Journal of Comparative Economics 30(2), 329353.

Démurger, S., M. Gurgand, S. Li, and X. Yue (2009). Migrants as second-class workers in urban China? A decomposition analysis. Journal of Comparative Economics 37(4), $610-628$.

Duan, C., K. Yang, F. Zhang, and X. Lu (2008). Nine trends in changes of floating population in China since the economic reform. Population Research (Ren Kou Yan Jiu) 32, 30-43.

Fleisher, B. and D. Yang (2008). China's evolving labor market. In B. Fleisher, N. Hope, A. Pena, and D. Yang (Eds.), Policy Reform and Chinese Markets: Progress and Challenges, pp. 125-158. Edward Elgar. 
Ge, S. and D. T. Yang (2010). Accounting for rising wages in China. Working Paper, The Chinese University of Hong Kong.

Hansen, B. (1969). Employment and wages in rural Egypt. American Economic Review 59(3), 298-313.

Hsieh, C. and P. Klenow (2009). Misallocation and manufacturing TFP in China and India. Quarterly Journal of Economics 124(4), 1403-1448.

Huang, Y. (2004). A labor shortage in China. Wall Street Journal Asia August 6, A7.

Huffman, W. (1980). Farm and off-farm work decisions: the role of human capital. Review of Economics and Statistics 62(1), 14-23.

Jorgenson, D. (1967). Surplus agricultural labour and the development of a dual economy. Oxford Economic Papers 19(3), 288-312.

Kennan, J. and J. Walker (2009). The effect of expected income on individual migration decisions. Econometrica, forthcoming.

Knight, J., Q. Deng, and L. Shi (2010). The puzzle of migrant labour shortage and rural labour surplus in China. Working Paper, University of Oxford.

Lewis, W. (1954). Economic development with unlimited supplies of labour. The Manchester School 22(May), 139-92.

Li, Q., A. De Brauw, S. Rozelle, and L. Zhang (2005). Labor market emergence and returns to education in rural China. Applied Economic Perspectives and Policy 27(3), 418-424.

Lin, J. (1992). Rural reforms and agricultural growth in China. American Economic Review 82(1), 34-51.

Maurer-Fazio, M. (1999). Earnings and education in China's transition to a market economy survey evidence from 1989 and 1992. China Economic Review 10(1), 17-40.

Meng, X. and M. Kidd (1997). Labor market reform and the changing structure of wage determination in China's state sector during the 1980s. Journal of Comparative Economics 25(3), 403-421.

Meng, X. and J. Zhang (2001). The two-tier labor market in urban China: occupational segregation and wage differentials between urban residents and rural migrants in Shanghai. Journal of Comparative Economics 29(3), 485-504. 
Minami, R. (1968). The turning point in the Japanese economy. Quarterly Journal of Economics 82(3), 380-402.

Minami, R. and M. Xin (2008). The turning point of the Chinese economy: Compared with Japanese experience. In Study Meeting of the Chinese Labor Market, Volume 20.

Psacharopoulos, G. (1994). Returns to investment in education: A global update. World Development 22(9), 1325-1343.

Ranis, G. (1988). Analytics of development: Dualism. In H. Chenery and T. Srinivasan (Eds.), Handbook of Development Economics, Volume 1, pp. 73-92. North Holland.

Ranis, G. and J. Fei (1961). A theory of economic development. American Economic Review 51(4), 533-565.

Reynolds, L. (1965). Wages and employment in a labor-surplus economy. American Economic Review 55(1), 19-39.

Rosenzweig, M. (1980). Neoclassical theory and the optimizing peasant: An econometric analysis of market family labor supply in a developing country. Quarterly Journal of Economics 94(1), 31-55.

Rosenzweig, M. (1988). Labor markets in low-income countries. In H. Chenery and T. Srinivasan (Eds.), Handbook of Development Economics, Volume 1, pp. 713-762. North Holland.

Rozelle, S., L. Guo, M. Shen, A. Hughart, and J. Giles (2009). Leaving China's farms: survey results of new paths and remaining hurdles to rural migration. China Quarterly 158, 367393.

Schultz, T. (1964). Transforming traditional agriculture. Yale Univ. Press.

Sheng, L. (2008). Floating or migration? Economic analyis of floating labor from rural China. Shanghai Yuandong Press.

Todaro, M. (1969). A model of labor migration and urban unemployment in less developed countries. American Economic Review 59(1), 138-148.

Topel, R. (1986). Local labor markets. Journal of Political Economy 94(3), S111-S143.

Yang, D. (1997). Education and off-farm work. Economic Development and Cultural Change 45(3), 613-632. 
Yang, D. (1999). Urban-biased policies and rising income inequality in China. American Economic Review 89(2), 306-310.

Yang, D. (2004). Education and allocative efficiency: household income growth during rural reforms in China. Journal of Development Economics 74(1), 137-162.

Yang, D. (2005). Determinants of schooling returns during transition: Evidence from Chinese cities. Journal of Comparative Economics 33(2), 244-264.

Yang, D., V. Chen, and R. Monarch (2010). Rising wages: Has China lost its global labor advantage? Pacific Economic Review 15(4), 482-504.

Yang, D. and H. Zhou (1999). Rural-urban disparity and sectoral labour allocation in China. Journal of Development Studies 35(3), 105-133.

Zhang, H., L. Zhang, R. Luo, and Q. Li (2008). Does education still pay off in rural China: Revisit the impact of education on off-farm employment and wages. China \& World Economy 16(2), 50-65.

Zhang, J., Y. Zhao, A. Park, and X. Song (2005). Economic returns to schooling in urban China, 1988 to 2001. Journal of Comparative Economics 33(4), 730-752.

Zhang, X., J. Yang, and S. Wang (2010). China has reached the Lewis turning point. IFPRI discussion paper.

Zhao, Y. (1999). Labor migration and earnings differences: the case of rural China. Economic Development and Cultural Change 47(4), 767-782.

Zhu, N. (2002). The impacts of income gaps on migration decisions in China. China Economic Review 13, 213-230. 